\title{
Exposure of black youths to cigarette advertising in magazines
}

Charles King III, Michael Siegel, Linda G Pucci

Graduate School of Business Administration, Harvard University, Boston,

Massachusetts, USA C King III

Social and Behavioral Sciences Department, Boston University School of Public

Health, Boston, Massachusetts, USA M Siegel

Management Decision and Research Center, VA Medical Center, Boston,

Massachusetts, USA

L G Pucci

Correspondence to: Dr Michael Siegel, Boston University School of Public Health, Social and Behavioral Sciences Department, 715 Albany Street, TW2, Boston, MA 02118, USA;

mbsiegel@bu.edu.

Received 9 July 1999. Accepted 3 October, 1999

\begin{abstract}
Objective-To estimate the potential exposure of black adolescents to brand specific advertising in magazines.

Design-A probit regression analysis was conducted of pooled 1990 and 1994 data on brand specific advertising in 36 popular US magazines to examine the relationship between the presence or absence of advertising in each magazine for each of 12 cigarette brands, and the proportion of each magazine's youth (ages 12-17 years) readers who were black.
\end{abstract}

Main outcome measures-The presence or absence of advertising in each magazine in 1990 and 1994, for each of 12 cigarette brands.

Results-After controlling for total magazine readership and the percentage of young adult, Hispanic, and female readers, black youth cigarette brands (those whose market share among black youths exceeded their overall market share) were more likely than other brands to advertise in magazines with a higher percentage of black youth readers. Holding all other variables constant at their sample means, the probability of a non-black youth brand advertising in a magazine decreased over the observed range of percentage black youth readership from 0.65 (95\% confidence interval (CI) 0.55 to 0.75 ) for magazines with $5 \%$ black youth readers to $0.33(95 \%$ CI 0.00 to 0.69 ) for magazines with $91 \%$ black youth readers. In contrast, the probability of a black youth brand advertising in a magazine increased from 0.40 (95\% CI 0.17 to 0.62 ) at $5 \%$ black youth readership to $1.00(95 \%$ CI 0.97 to 1.00$)$ at $91 \%$ black youth readership.

Conclusions-Black youths are more likely than white youths to be exposed to magazine advertising by cigarette brands popular among black adolescents.

(Tobacco Control 2000;9:64-70)

Keywords: advertising; magazines; youths

Introduction

After declining steadily from 1974 to $1991,{ }^{1-3}$ smoking prevalence among black adolescents increased by $80 \%$ between 1991 and 1997, rising from $12.6 \%$ to $22.7 \%$ among all black high school students and doubling from $14.1 \%$ to $28.2 \%$ among black males. ${ }^{45}$ After declining steadily from 1965 to 1990, smoking prevalence among black adults has remained stable since $1990 .^{67}$ This lack of progress in reducing smoking among black Americans is disappointing, especially since blacks already bear the greatest burden of tobacco related mortality of any racial or ethnic group. ${ }^{4}$

One potential explanation for the increase in smoking rates among black youths might be an increase in exposure to cigarette advertising. Assessing the nature and extent of exposure to cigarette advertising among black youths is therefore central to the public health debate about interventions to reduce smoking in this population. Because magazine advertising represents $46 \%$ of all tobacco industry advertising, ${ }^{8}$ understanding the exposure of black youths to cigarette advertising in magazines is particularly important.

Previous studies have provided limited information on the exposure of black adults to cigarette advertising in magazines. Several studies have anecdotally reported a high level of cigarette advertisement spending in magazines with high black readerships. ${ }^{9-12}$ Without comparing cigarette advertising in non-black magazines, however, these studies cannot examine differences in exposure to advertising among black and white readers.

Four studies have compared cigarette advertising in black oriented and non-black oriented magazines. ${ }^{13-16}$ Cummings and colleagues studied cigarette advertisements in seven magazines in 1984-85 and found that black oriented magazines contained more cigarette advertisements and more advertisements for menthol brands than white oriented magazines. ${ }^{13}$ Basil and colleagues studied one issue per year from 10 magazines for the years 1924 to 1989 and found that while the number of advertisements in general, men's, and women's magazines declined during the late 1980s, the number of advertisements in black magazines remained stable. ${ }^{14}$ The content of advertisements in black magazines differed from that in other magazines. Advertisements in black magazines were more likely to include themes of horseplay, coy model poses, and erotic romantic contact, and the models in these advertisements were more likely to be black. Pollay and colleagues compared cigarette advertisements in Ebony and Life magazines for the years 1950 to 1965 and found that advertisements in Ebony were more likely to use black models and athletes, and that these advertisements became more prevalent in Ebony than Life over time. ${ }^{15}$ Yach and Paterson studied brand specific advertising expenditures in relation to magazine demographics for 10 South African magazines during a three month period in 1993 and 
found that menthol brands were more likely to be advertised in black magazines. ${ }^{16}$

Although these studies suggest that black adults may be preferentially exposed to certain themes and to certain cigarette brands in magazine advertising, we are aware of no previous study that has examined the exposure of black adolescents to cigarette advertising in magazines. Most previous research has relied on comparison of advertising patterns in relatively few magazines, and none has systematically examined advertising by a large sample of cigarette brands in a nearly complete sample of the major magazines. Finally, no previous study has investigated patterns of advertising in relation to the number of black youth readers in magazines or differences in advertising patterns between brands that are popular among black youths and those that are not.

In this study, we examine whether black adolescents are more likely than white adolescents to be exposed to magazine advertising by cigarette brands popular among black youths. The analysis addresses the major limitations of previous research by: (1) studying advertising in a nearly complete sample of the largest US magazines during the years 1990 and 1994 ; (2) using specific data on the number of black adult or black youth readers for each magazine; and (3) using brand specific cigarette advertising data for a large sample of brands, and comparing brands smoked by a substantial proportion of black youths to those smoked predominantly by adults or white youths.

Although a finding that cigarette brands popular among black adolescents are more likely to advertise in magazines with more black readers cannot demonstrate an intent on the part of cigarette advertisers to expose adolescents to their advertising messages, such a finding would document that black adolescents are more likely to be exposed to advertising by those cigarette brands that are popular among black youth smokers. From a public health perspective, youth exposure to advertising is important, regardless of whether cigarette companies intend to expose youths. To the best of our knowledge, this is the first study to examine the relative exposure of black adolescents to magazine advertising by different cigarette brands.

\section{Methods}

MODEL OF ADVERTISING BEHAVIOUR

This study extends previous research in which we examined whether cigarette brands that are popular among youth smokers are more likely to advertise in magazines with a higher percentage of youth readers. ${ }^{17}$ We model the advertising behaviour of cigarette brands in terms of the probability that a given cigarette brand will advertise in a particular magazine, using pooled data for 1990 and 1994. The dependent variable is the presence or absence of advertising for a specific brand in a given magazine in 1990 or 1994 . The predictor variables in our model include: (1) the demographic characteristics of a magazine's readership, including the total number of read- ers (ages 12 and older) and the percentage of readers in various demographic subgroups (black youths (ages 12-17), white youths, black adults (ages 18+), young adults (ages 18-24), females, smokers, heavy smokers, and menthol smokers); (2) the cost of placing an advertisement in a given magazine (the cost of a full page, four colour advertisement); (3) the number of annual magazine issues; (4) the total advertising expenditures available to a cigarette brand; and (5) the median income of magazine readers.

Using a probit model, and controlling for the other factors that might affect the probability of advertising, we have analysed whether cigarette brands that are popular among black adolescent smokers ("black youth brands") are more likely than brands smoked predominantly by adults or white youths ("non-black youth" or "other" brands) to advertise in magazines with a high percentage of black youth readers (defined as the percentage of youth readers who are black) or black adult readers (defined as a percentage of all readers). Since only the outcome of the advertising decision is observed, the empirical specification employs a binary choice model of advertising behaviour where the dependent variable is 1 if a given cigarette brand advertises in a particular magazine and 0 if it does not. We used a probit model to examine the relationship between the presence or absence of cigarette advertising in a magazine and the magazine's readership characteristics.

\section{REGRESSION SPECIFICATION}

The estimation of the model requires observations on which cigarette brands advertise in which magazines and data on the brand and magazine explanatory variables. An observation consists of a brand-magazine pair where the dependent variable is the presence of advertising by a particular brand in a given magazine, measured as a dichotomous variable ( 1 if a cigarette brand advertised in a given magazine in 1990 or 1994,0 if the brand did not advertise in that magazine).

To assess possible differences in the advertising behaviour of black youth and non-black youth cigarette brands, we constructed an indicator variable, $\delta$, that is 0 for non-black youth brands and 1 for black youth brands, and created an additional series of regressors by multiplying each explanatory variable by $\delta$. These interaction variables allowed us to estimate separate regression coefficients for black youth and non-black youth brands. For example, the interaction variable for black youth readership is defined as $\delta$ * (\% black youth readers). This interaction variable enables us to measure potential differences in the advertising patterns for non-black youth and black youth brands with respect to the level of black youth readership in magazines in which they advertise.

A regression coefficient of zero for the black youth readership interaction variable would indicate that black youth and non-black youth brands are equally likely to advertise in magazines, regardless of the level of black youth readership. A positive coefficient would 
Table 1 Black youth readership and tobacco advertising expenditures in 36 magazines

\begin{tabular}{|c|c|c|c|}
\hline Magazine & $\begin{array}{l}\% \text { Black } \\
\text { youth } \\
\text { readers }\end{array}$ & $\begin{array}{l}\text { Total pages of } \\
\text { cigarette } \\
\text { advertising, } \\
1990 \text { and } \\
1994+\end{array}$ & $\begin{array}{l}\text { Total expenditures for } \\
\text { cigarette advertising, } 1990 \\
\text { and } 1994 \text { (in millions of } \\
1994 \text { dollars) } t\end{array}$ \\
\hline \multicolumn{4}{|l|}{ Black youth magazines $\ddagger$} \\
\hline Jet & 85.8 & 120.2 & 2.7 \\
\hline Ebony & 85.2 & 107.0 & 4.6 \\
\hline Essence & 81.5 & 95.7 & 3.3 \\
\hline Total, black youth magazines & 84.7 & 322.9 & 10.5 \\
\hline \multicolumn{4}{|l|}{ Other magazines } \\
\hline GQ & 33.5 & 97.0 & 3.6 \\
\hline True Story & 26.3 & 118.6 & 2.9 \\
\hline McCalls & 26.2 & 73.2 & 7.1 \\
\hline Better Homes and Gardens & 24.3 & 61.0 & 9.4 \\
\hline New Woman & 23.0 & 134.7 & 4.3 \\
\hline Life & 22.9 & 119.7 & 8.6 \\
\hline Soap Opera Digest & 21.7 & 130.5 & 3.9 \\
\hline Sport & 21.1 & 99.2 & 2.9 \\
\hline Sporting News & 20.6 & 65.6 & 1.7 \\
\hline Car and Driver & 19.7 & 112.0 & 7.0 \\
\hline Road and Track & 19.4 & 95.5 & 4.4 \\
\hline Vogue & 18.3 & 116.7 & 6.3 \\
\hline Redbook & 17.9 & 95.0 & 7.6 \\
\hline Family Circle & 17.8 & 82.9 & 9.2 \\
\hline TV Guide & 17.5 & 200.3 & 27.3 \\
\hline Time & 16.9 & 118.5 & 20.9 \\
\hline Popular Science & 16.8 & 25.3 & 1.6 \\
\hline Sports Illustrated & 16.6 & 300.9 & 47.8 \\
\hline Woman's Day & 16.2 & 108.3 & 10.6 \\
\hline People & 15.7 & 349.3 & 44.1 \\
\hline Glamour & 15.6 & 151.1 & 11.1 \\
\hline Us & 15.0 & 164.6 & 6.7 \\
\hline Motor Trend & 14.4 & 87.6 & 3.9 \\
\hline Newsweek & 13.6 & 75.2 & 12.8 \\
\hline Self & 11.9 & 79.8 & 3.9 \\
\hline Mademoiselle & 11.2 & 138.6 & 6.9 \\
\hline Cosmopolitan & 11.1 & 181.5 & 14.9 \\
\hline Hot Rod & 11.0 & 141.5 & 4.7 \\
\hline Popular Mechanics & 10.4 & 67.9 & 4.5 \\
\hline Field and Stream & 10.0 & 103.7 & 7.2 \\
\hline Elle & 9.9 & 96.3 & 4.3 \\
\hline Rolling Stone & 8.3 & 260.7 & 13.1 \\
\hline Outdoor Life & 8.0 & 82.7 & 4.3 \\
\hline Total, other magazines & 16.9 & 4135.2 & 329.6 \\
\hline Total, all magazines & 21.9 & 4457.9 & 340.1 \\
\hline
\end{tabular}

From Simmons Market Research Bureau, Inc, ${ }^{21-23}$ Teenage Research Unlimited, ${ }^{24}$ Mediamark Research Inc, ${ }^{25}$ and Leading National Advertisers. ${ }^{18} 19$

*The percentage of black youth readers is defined as the ratio of the number of black readers ages $12-17$ to the number of all readers ages $12-17$. Values given are the average percentage black youth readership for the years 1990 and 1994 combined.

†Total pages or expenditures for advertising among the 12 cigarette brands in our study, added for the years 1990 and 1994. All expenditures are in 1994 dollars, using a cost index for magazine advertising. ${ }^{33}$

$\ddagger$ Black youth magazines are defined as those for which greater than $75 \%$ of youth (ages $12-17$ ) readers are black. readers $=($ black readers ages $12-17) /($ total readers ages $12-17$ )

By including both a variable and its interaction term in the regression specification, we can determine whether differences in the likelihood that black youth and non-black youth brands advertise in a magazine are significant for each independent variable in the model. For example, the coefficient $B$ reflects the change in likelihood of advertising as black youth readership increases for non-black youth cigarette brands, and the coefficient $\left(B+B_{i}\right)$ reflects the change in likelihood of advertising as black youth readership increases for black youth brands. Under the null hypothesis- that the probability of a cigarette brand advertising in a magazine is unrelated to the magazine's black youth readership - both the coefficients $B$ and $B_{i}$ would be 0 . If black youth brands, but not other brands, were more likely to advertise in magazines with higher black youth readership, then the coefficient $B$ would be 0 , but the coefficient $\left(B+B_{i}\right)$ would be positive ( $B_{i}$ would be positive).

The significance of the coefficient $B_{i}$ allows us to assess the significance of any difference between black youth and non-black youth brands in the likelihood of advertising in magazines at varying levels of black youth readership.

MAGAZINE SAMPLE SELECTION

To select a sample of magazines for analysis, we identified all magazines for which data on adult and youth readership and data on brand specific cigarette advertising were available for the years 1990 and 1994. The final sample consisted of 36 magazines (table 1). We are not aware of any major magazines with large numbers of black readers that were excluded from our sample.

\section{DATA SOURCES}

\section{Magazine advertising expenditures}

From the Leading National Advertisers Brand Detail Report for 1990 and 1994, we determined whether each cigarette brand advertised in each of the 36 magazines in 1990 and 1994 and estimated each brand's total expenditures for advertising in the 36 magazines in 1990 and $1994 .^{18} 19$ These estimates of advertising expenditures are based on the number of pages of advertising and the price per advertising page for the magazine, not on actual dollars negotiated with a publisher.

\section{Cost of advertising}

We used the SRDS Consumer Magazine Advertising Source to obtain the cost for a single, full page, four colour advertisement in each magazine in 1990 and 1994 and the annual number of issues for each magazine. ${ }^{20}$

\section{Adult magazine readership}

We obtained data on the adult (ages 18 and older) readership for each magazine from the 1990 and 1994 Study of Media and Markets, ${ }^{21-23}$ produced by the Simmons Market Research Bureau, Inc. From the Simmons data, we also collected the following demographic informa-
Here $\delta=1$ for black youth brands and $\delta=0$ for non-black youth brands, and \% black youth 
Table 2 Tobacco advertising in black oriented and non-black oriented magazines, by brand, 1990 and 1994

\begin{tabular}{|c|c|c|c|c|c|c|}
\hline Brand & $\begin{array}{l}\text { Black youth } \\
\text { market share, } \\
\text { 1989* }\end{array}$ & $\begin{array}{l}\text { Black youth } \\
\text { market share, } \\
\text { 1993* }\end{array}$ & $\begin{array}{l}\text { Pages of advertising, } \\
1990 \text { and 1994, black } \\
\text { magazinest }\end{array}$ & $\begin{array}{l}\text { Pages of advertising, } \\
1990 \text { and 1994, other } \\
\text { magazinest }\end{array}$ & $\begin{array}{l}\text { Expenditures for } \\
\text { advertising, } 1990 \text { and } \\
\text { 1994, black magazines } \\
\text { (in millions of } 1994 \\
\text { dollars) } t\end{array}$ & $\begin{array}{l}\text { Expenditures for } \\
\text { advertising, } 1990 \text { and } \\
1994 \text {, other magazines } \\
\text { (in millions of } 1994 \\
\text { dollars) } t\end{array}$ \\
\hline \multicolumn{7}{|l|}{ Black youth brands $\ddagger$} \\
\hline Newport & 61.3 & 70.4 & 80.0 & 297.1 & 2.6 & 22.1 \\
\hline Kool & 10.9 & 11.9 & 42.4 & 189.0 & 1.4 & 16.2 \\
\hline Salem $\ddagger(1989)$ & 9.7 & - & 30.0 & 116.2 & 1.0 & 9.5 \\
\hline Total, black youth brands & & & 152.4 & 602.3 & 5.0 & 47.8 \\
\hline Marlboro & 8.7 & 8.5 & 0 & 1114.3 & 0 & 84.5 \\
\hline Benson \& Hedges & 3.3 & 1.7 & 71.6 & 389.5 & 2.2 & 37.6 \\
\hline Camel & 3.1 & 0 & 0 & 466.1 & 0 & 31.7 \\
\hline Salem $\ddagger(1993)$ & - & 1.4 & 4.0 & 16.0 & 0.1 & 1.3 \\
\hline Winston & 0 & 0 & 0 & 167.8 & 0 & 11.5 \\
\hline Merit & 0 & $<5.5$ & 0 & 477.1 & 0 & 48.9 \\
\hline Virginia Slims & $<2.9$ & 0.5 & 70.8 & 531.2 & 2.4 & 38.8 \\
\hline Parliament & $<2.9$ & $<5.5$ & 0 & 76.7 & 0 & 6.9 \\
\hline Kent & $<2.9$ & $<5.5$ & 0 & 2.0 & 0 & 0.4 \\
\hline Capri & $<2.9$ & $<5.5$ & 24.0 & 272.1 & 0.9 & 20.3 \\
\hline Total, all brands & & & 322.8 & 4115.1 & 10.6 & 329.7 \\
\hline
\end{tabular}

Youth readership data from Teenage Research Unlimited ${ }^{24}$ and Mediamark Research Inc $^{25}$; advertising data from Leading National Advertisers. ${ }^{18} 19$

${ }^{\star}$ Black youth market share is the proportion of all black youth (ages 12-18) smokers who smoke that brand. Market share data is from the Centers for Disease Control and Prevention's Teenage Attitudes and Practices Survey (TAPS) ${ }^{29}$ for 1990 and Teenage Attitudes and Practices Survey II (TAPS II) ${ }^{30}$ for 1994.

†Total pages or expenditures for advertising for the given brand(s), added for the years 1990 and 1994 . All expenditures are in 1994 dollars, using a cost index for magazine advertising. ${ }^{33}$ Black magazines are defined as those for which greater than $75 \%$ of youth (ages $12-17$ ) readers are black.

$\ddagger$ Black youth brands are defined as those whose black youth market share (from TAPS ${ }^{29}$ or TAPS II $^{30}$ ) is greater than its overall market share (from the Maxwell

Consumer Report ${ }^{31}{ }^{32}$ ). Salem was defined as a black youth brand in 1989, but not in 1994. Data shown for Salem refer only to the year for which Salem was considered to be in the relevant brand category.

tion about adult readers for each magazine: median individual income; percentage of female, black, Hispanic, and young adult (ages 18-24) readers; and percentage of readers who are smokers, heavy smokers ( $\geqslant 30$ cigarettes per day), and smokers of menthol brands.

\section{Youth magazine readership}

We obtained data on the number of youth (ages 12-17) readers, white youth readers, and black youth readers for each magazine from the 1990 and 1994 Teenage Research Unlimited (TRU) study and from the Mediamark Research Inc (MRI) Teenmark/Twelve Plus studies. $^{2425}$

DATA COLLECTION

We extracted the data from the above publications and entered it into an Excel spreadsheet. We verified data entry by comparing printouts of the spreadsheet with the data in each publication. After verification, we created an SAS data set by converting the Excel spreadsheet using DBMS/COPY. ${ }^{26}$ We used $\mathrm{SAS}^{27}$ and Stata $^{28}$ to conduct all analyses.

\section{CLASSIFICATION OF BLACK YOUTH AND}

NON-BLACK YOUTH BRANDS

To avoid potential misclassification of brands such as Marlboro (which, with their large overall market share, other things being equal, have large shares among minority subpopulations simply because of their intrinsic size), we defined black youth brands as those for which the market share among black youths (the ratio of black youth smokers who smoked that brand to all black youth smokers) was greater than the overall market share for that brand among all smokers. We obtained data on black youth market shares from the national Teenage Attitudes and Practices Survey (TAPS) and the Teenage Attitudes and Practices Survey II (TAPS II) conducted by the Centers for Disease Control and Prevention in 1989 and
1993, respectively. ${ }^{29}{ }^{30}$ We obtained information on the overall market share for each cigarette brand from the Maxwell Consumer Reports for 1989 and 1993..$^{32}$

Based on this definition, we classified Newport and Kool as black youth brands for both 1989 and 1993 and Salem as a black youth brand for 1989, but not 1993 (table 2). Brands classified as non-black youth brands for both years were Marlboro, Camel, Winston, Benson \& Hedges, Virginia Slims, Merit, Capri, Kent, and Parliament (table 2). For brands not referenced by name in TAPS or TAPS II, we can only state that their black youth market shares were less than the percentages for the "other" brand category reported in those surveys.

We used brand market share data for the year preceding the magazine advertising data to alleviate the potential problem of advertising simultaneously affecting black youth market share.

\section{Results}

DESCRIPTIVE ANALYSIS

Three magazines-Ebony, Essence, and fethad greater than $80 \%$ black youth readership (defined as the proportion of youth (ages 12-17) readers who are black among all youth readers) in 1990 and 1994 (table 1). The next highest level of black youth readership was $33.5 \%$ for $G Q$.

The 12 cigarette brands in the study allocated a total of 322.8 pages of advertisements to the three black oriented magazines and 4135.2 pages of advertisements to the other 33 magazines in 1990 and 1994 (table 1). Total cigarette advertisement expenditures for the 12 brands were $\$ 10.5$ million in the black oriented magazines and $\$ 329.6$ million in the other magazines. Thus, $7.2 \%$ of cigarette advertising pages and $3.1 \%$ of advertising expenditures appeared in the black oriented magazines. 
Table 3 Results from probit regression model: the effect of magazine readership characteristics on the probability of a cigarette brand advertising in a magazine

\begin{tabular}{lll}
\hline Independent variablet & Coefficient & Standard error \\
\hline$\%$ Black youth readers & -0.957 & 0.728 \\
$\delta^{\star}$ (\% Black youth readers) & $4.389^{\star \star}$ & 1.808 \\
\% Young adult readers & $3.688^{\star \star}$ & 1.224 \\
$\delta^{\star}$ (\% Young adult readers) & -1.804 & 2.705 \\
$\%$ Female readers & $0.878^{\star \star}$ & 0.296 \\
$\delta^{\star}$ (\% Female readers) & -0.849 & 0.704 \\
$\%$ Hispanic readers & -1.903 & 2.587 \\
$\delta^{\star}$ (\% Hispanic readers) & 3.721 & 5.850 \\
Total readers & $40.778^{\star \star}$ & 14.754 \\
$\delta^{\star}$ Total readers & 3.066 & 33.893 \\
$\%_{\text {Smokers }}$ & -0.674 & 1.938 \\
$\delta^{\star}$ (\% Smokers) & 4.989 & 4.154 \\
$\%^{\star}$ Heavy smokers & -0.062 & 5.553 \\
$\delta^{\star}$ (\% Heavy smokers) & 13.555 & 13.074 \\
$\%^{\star}$ Menthol smokers & -2.919 & 4.024 \\
Cost of ad & -3.602 & 9.253 \\
$\delta^{\star}$ Cost of ad & $-905.855^{\star}$ & 548.269 \\
Total expenditures & -1023.603 & 1254.493 \\
$\delta^{\star}$ Total expenditures & $58.956^{\star \star}$ & 7.866 \\
Issues & -17.063 & 35.559 \\
$\delta^{\star}$ Issues & -0.004 & 0.006 \\
Income & $0.024^{\star}$ & 0.014 \\
$\delta^{\star}$ Income & -0.105 & 0.284 \\
Constant & $-1.761^{\star \star}$ & 0.709 \\
$\delta$ & 1.453 & 1.773 \\
\hline & -0.355 & 0.725 \\
\hline
\end{tabular}

$\dagger \delta$ is 0 for non-black youth cigarette brands and 1 for black youth cigarette brands.

${ }^{\star}$ Coefficient is significant at the $90 \%$ level $(\mathrm{p}<0.10)$.

${ }^{\star \star}$ Coefficient is significant at the $95 \%$ level $(\mathrm{p}<0.05)$.

Black youth cigarette brands allocated 152.4 pages, or $20.2 \%$ of their total advertisement pages, to the three black oriented magazines, while non-black youth cigarette brands allocated only $4.6 \%$ of their advertisement pages to these magazines (table 2). Similarly, black youth brands spent $\$ 5.0$ million, or $9.5 \%$ of their total advertisement expenditures, in the black oriented magazines, while non-black youth brands spent only $1.9 \%$ of their advertisement expenditures in black oriented magazines. The proportion of total advertising allocated to black oriented magazines by black youth cigarette brands was more than four times higher than the proportion of total advertising allocated to these magazines by non-black youth brands.

Advertising by black youth brands accounted for $47.2 \%$ of the pages devoted to cigarette advertisements in black oriented magazines but only $14.6 \%$ of those pages in non-black oriented magazines (table 2). Similarly, black youth brands accounted for $47.2 \%$ of the total cigarette advertisement expenditures in black oriented magazines but only $14.5 \%$ of those expenditure in non-black oriented magazines. The advertising levels for black youth cigarette brands in black oriented magazines were more than three times greater than for non-black youth brands in these magazines.

PROBIT REGRESSION ANALYSIS

Eight variables - black youth readership, young adult readership, female readership, total readership, median income of magazine readers, the cost of advertising in a magazine, total advertising expenditures for a given cigarette brand, and the number of annual magazine issues - were found to affect significantly the probability that a cigarette brand would advertise in a given magazine (table 3 ).

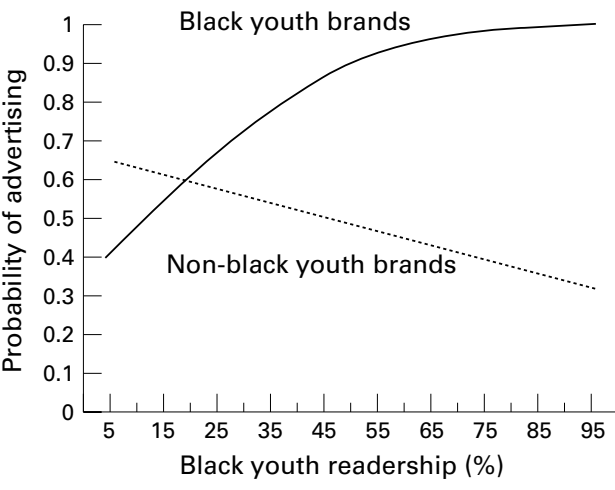

Figure 1 Probability that a cigarette brand is advertised in a magazine as a function of the magazine's percentage of youth readers who are black, holding all other variables fixed at their mean values in the sample-black youth versus non-black youth cigarette brands.

The only magazine readership variables that had significantly different coefficients for black youth and non-black youth brands were income and black youth readership (table 3). Black youth brands were more likely to advertise in magazines as the median income of magazine readers decreased. For non-black youth brands, there was no association between the probability of advertising and the median income of magazine readers.

The probability of advertising in a magazine decreased with the percentage of black youth readers for non-black youth brands but increased significantly with the percentage of black youth readers for black youth brands (table 3). In other words, non-black youth brands were less likely, although not significantly so, to advertise in magazines as the percentage of black youth readers increased, and black youth brands were significantly more likely to advertise in magazines as the percentage of black youth readers increased.

Holding all other variables constant at their sample means, the probability of a non-black youth brand advertising in a magazine decreased from 0.65 (95\% confidence interval (CI) 0.55 to 0.75 ) at a black youth readership level of $5 \%$ (the lowest level in the sample magazines), to 0.59 (95\% CI 0.55 to 0.63 ) at a black youth readership of $23 \%$ (the mean level for all magazines), to 0.33 (95\% CI 0.00 to 0.69 ) at a black youth readership level of $91 \%$ (the highest level in the sample magazines) (fig 1). In contrast, the probability of a black youth brand advertising in a magazine increased from $0.40(95 \%$ CI 0.17 to 0.62$)$ at a black youth readership level of $5 \%$ to 0.64 (95\% CI 0.52 to 0.75 ) at a black youth readership level of $23 \%$, to 1.00 (95\% CI 0.97 to 1.00$)$ at a black youth readership level of $91 \%$.

The ratio of the probability of advertising for a black youth brand compared to a non-black youth brand increased with increasing black youth readership (fig 2). At a black youth readership level of $20 \%$ with all other variables evaluated at their mean values, the ratio of advertising probabilities was 1.00 (95\% CI 1.00 to 1.00 ), indicating that black youth and non-black youth brands were equally likely to advertise in these magazines. At a black youth readership level of $5 \%$, the ratio of probabilities 


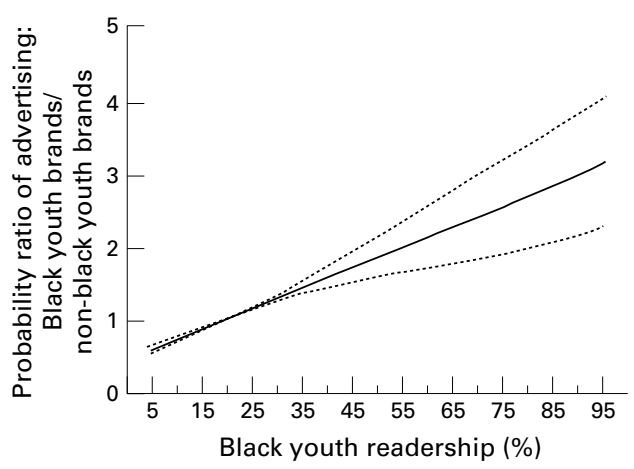

Figure 2 Ratio of the probability that a black youth cigarette brand is advertised in a magazine to the probability that a non-black youth brand is advertised in that magazine as a function of the magazine's percentage of black youth readers, holding all other variables fixed at their mean values in the sample (95\% CI shown).

was 0.61 (95\% CI 0.54 to 0.67 ), indicating that black youth brands were only $60 \%$ as likely to advertise in these magazines. At a black youth readership level of $91 \%$, the ratio was 2.99 (95\% CI 2.17 to 3.82 ), indicating that black youth brands were about three times more likely to advertise in such magazines.

We found that the percentages of black adult, black youth, and total black readers were highly correlated (correlation coefficients $>0.95)$. When the percentage of black adult readers (the number of black adult readers divided by the total number of adult readers) or the overall percentage of black readers (the number of black youth and adult readers divided by the total number of readers) was substituted for the percentage of black youth readers in the regression model, the results were similar. In both cases, non-black youth brands were less likely to advertise in magazines as black readership increased, and black youth brands were more likely to advertise in magazines as black readership increased. Because of the high correlations, we could not differentiate the effects of black youth versus black adult readership on the probability of advertising.

\section{Discussion}

To the best of our knowledge, this paper is the first to investigate exposure to cigarette advertising in magazines among black youths by examining the relationship between cigarette brand specific advertising and black youth readership among a large, nearly complete sample of the most highly read magazines in two full years. It is also the first study of cigarette advertising in magazines to compare advertising patterns for brands that are smoked by black adolescents with those smoked predominantly by adults and white adolescents. We found that black adolescents were more likely than white adolescents to be exposed to cigarette magazine advertising for brands popular among black youths. Our data suggest that black youths are preferentially exposed to magazine advertising by precisely those cigarette brands that are popular among black youth smokers.

That black adolescents are disproportionately exposed to magazine advertising for brands popular among these youths suggests that this advertising may have an effect on smoking behaviour among black youths. Previous research has documented a relationship between total brand specific advertising expenditures and changes in youth market shares among cigarette brands from 1989 to $1993,{ }^{30}$ and has demonstrated that youth brand market shares were three times more responsive to changes in advertising share of voice than adult brand market shares during the period 1979 to $1993 .^{34}$ Our findings add to this research by demonstrating a relationship between exposure to brand specific advertising in magazines among black youths and cigarette brand market shares among black youth smokers. Although this does not necessarily imply an effect of advertising on smoking initiation, it does suggest an effect on cigarette brand choice, a critical component of the smoking initiation process. ${ }^{35}$ Pierce and colleagues recently showed that exposure to cigarette advertising and promotion does influence teenagers to start smoking. ${ }^{36}$

Our finding that black youths are preferentially exposed to cigarette advertising by brands popular among these youths may seem "obvious". But it is important to note that both the legislative process, in considering tobacco policy, and the judicial process, in litigating tobacco cases, demand well documented, scientific evidence-not merely "obvious" or intuitive arguments. Previous research has documented increased exposure of black adults to cigarette advertising for brands popular among black smokers. However, this research is the first that we know of that documents higher levels of exposure to cigarette advertising among black adolescents for brands popular among this group of adolescents. Documenting this finding specifically among underage youths could have implications for public policy and tobacco litigation.

Cigarette advertising in black oriented magazines was limited to six cigarette brands (table 2), all of which are dominated by menthol varieties. This limitation of brand advertising in magazines read by large numbers of black youths to menthol cigarette brands, if representative of an historical pattern, may explain the high proportion (approximately 90\%) of menthol smokers among black adolescent smokers.

Our findings are subject to two important limitations. First, the results of this study do not necessarily imply that cigarette companies are specifically targeting black youths in their magazine advertising. We also found a strong relationship between black youth brand advertising patterns and black adult readership. The presence of strong multicolinearity between black adult and black youth magazine readership precludes distinguishing the effects of these variables on the probability of advertising. Thus, we cannot make inferences regarding the intent of cigarette companies to reach black youth readers. Their intent may be to reach black adult readers, and youth exposure occurs incidentally. From a public health perspective, what matters is whether 
adolescents are exposed to cigarette advertising that leads them to begin smoking, whether that exposure was intentional or not. We have documented that black youths are heavily exposed to cigarette advertising by the brands smoked by the majority of black youth smokers. Examining data over many years may allow future research to separate the effects of black youth and black adult readership on brand advertising decisions.

Second, although this study provides a quantitative examination of the relationship between cigarette brand advertising and black youth readership, it does not provide information on the qualitative aspects of these cigarette advertisements - for example, advertising themes and images and their potential appeal to black youths. One study has examined this question. Huang and colleagues have shown that black adolescents find cigarette magazine advertisements with black models more appealing than do white adolescents. ${ }^{37}$

Despite these limitations, our findings provide new evidence that black adolescents are preferentially exposed to advertising by those cigarette brands that are most popular among black adolescent smokers. This finding, when combined with the results of studies on the effect of cigarette marketing on smoking initiation, ${ }^{36}$ has important implications for public health policy. It suggests that cigarette advertising may influence smoking initiation among black youths. To counteract rising rates of smoking among black youths, public health interventions that reduce or eliminate exposure of these youths to cigarette advertising in magazines and other media may be beneficial.

This work was supported by grants from the Harvard Business School, Division of Research, and the Massachusetts Department of Public Health, Massachusetts Tobacco Control Program (Health Protection Fund).

1 Nelson DE, Giovino GA, Shopland DR, et al. Trends in cigarette smoking among US adolescents, 1974 through 1991. Am f Public Health 1995;85:34-40.

2 Giovino GA, Henningfield JE, Tomar SL, et al. Epidemiology of tobacco use and dependence. Epidemiol Rer 1995;17:48-65.

3 US Department of Health and Human Services. Preventing tobacco use among young people. A report of the Surgeon General, 1994. Atlanta, Georgia: Public Health Service, Centers for Disease Control and Prevention, Office on Smoking and Health, 1994. (US Government Printing Office Publication No S/N 017-001-00491-0.)

4 US Department of Health and Human Services. Tobacco use among U.S. raciallethnic minority groups: African Americans, American Indians and Alaska Natives, Asian Americans and Pacific Islanders, Hispanics. A report of the Surgeon General, 1998. Atlanta, Georgia: Centers for Disease Control and Prevention, Office on Smoking and Health, 1998. (US Government Printing Office Publication No S/N 017001-00527-4.)

5 Tobacco use among high school students-United States, 1997. MMWR Morb Mortal Wkly Rep 1998;47:229-33. 6 Giovino GA, Schooley MW, Zhu B. Surveillance for selected tobacco-use behaviors-United States,
1994. MMWR CDC Surveill Summ 1994;43:1-43.

7 Cigarette smoking among adults-United States, 1995. MMWR Morb Mortal Wkly Rep 1997;46:1217-20.

8 Federal Trade Commission (US). Federal Trade Commission report to Congress for 1994: Pursuant to the Federal Cigarette Labeling and Advertising Act. Washington, DC: Federa Trade Commission, 1996
9 Cooper R, Simmons BE. Cigarette smoking and ill health among black Americans. New York State fournal of Medicine 1985;85:344-9.

10 Davis RM. Current trends in cigarette advertising and marketing. N Engl f Med 1987;316:725-32.

11 Tuckson RV. Race, sex, economics, and tobacco advertising. f Natl Med Assoc 1989;81:1119-24.

12 Hoffman-Goetz L, Gerlach KK, Marino C, et al. Cancer coverage and tobacco advertising in African-American women's popular magazines. 7 Community Health 1997; 22:261-70.

13 Cummings KM, Giovino G, Mendicino AJ. Cigarette advertising and black-white differences in brand preferadvertising and black-white differences in
ence. Public Health Rep 1987;102:698-701.

14 Basil MD, Schooler C, Altman DG, et al. How cigarettes are advertised in magazines: special messages for special markets. Health Communication 1991;5:75-91.

15 Pollay RW, Lee JS, Carter-Whitney D. Separate, but not equal: racial segregation in cigarette advertising. Fournal of Advertising 1992;21:45-57.

16 Yach D, Paterson G. Tobacco advertising in South Africa with specific reference to magazines. $S$ Afr Med 7 1994;84:838-41.

17 King C, Siegel M, Celebucki C, et al.Adolescent exposure to cigarette advertising in magazines: an evaluation of brandspecific advertising in relation to youth readership. $7 A M A$ 1998;279:516-20.

18 Leading National Advertisers. 1990 brand detail report. New York: Leading National Advertisers, Publishers Information Bureau, Inc, 1990.

19 Leading National Advertisers. 1994 brand detail report. New York: Leading National Advertisers, Publishers Information Bureau, Inc, 1994.

20 Standard Rate and Data Service. SRDS consumer magazine advertising source. Des Plaines, Illinois: SRDS, 1998.

21 Simmons Market Research Bureau, Inc. Simmons study of media and markets. Publications: Total audiences (M1). New York: Simmons Market Research Bureau, Inc, 1990 and 1994.

22 Simmons Market Research Bureau, Inc. Simmons study of media and markets. Distilled spirits, mixed drinks, malt beverages, wine \& tobacco products (P14). New York: Simmons Market Research Bureau, Inc, 1990 and 1994.

23 Simmons Market Research Bureau, Inc. Simmons teen age research study (STARS). New York: Simmons Market Research Bureau, Inc, 1990 and 1994.

24 Teenage Research Unlimited. Teenage marketing \& lifestyle study: magazine readership data, 1986-1997. Northbrook, Illinois: Teenage Research Unlimited, 1998.

25 Mediamark Research Inc. Mediamark Research Inc. (MRI) Teenmark/Twelve Plus, 1991-1994. New York: Mediamark Research Inc, 1998.

26 Conceptual Software, Inc. DBMS/COPY: the tool for software connectivity, combined manual for Windows and DOS, version 5.0. Houston, Texas: Conceptual Software, Inc, 1994.

27 SAS Institute Inc. SAS/STAT software: changes and enhancements, release 6.10. Cary, North Carolina: SAS Institute Inc, 1994.

28 Stata Corporation. STATA statistical software: release 5.0. College Station, Texas: Stata Corporation, 1997.

29 Comparison of the cigarette brand preferences of adult and teenaged smokers-United States, 1989, and 10 US comteenaged smokers-United States, 1989, and 10 US com1992;41:169-73,179-81.

30 Changes in the cigarette brand preferences of adolescent smokers-United States, 1989-1993. MMWR Morb Mortal Wkly Rep 1994;43:577-81.

31 Maxwell JC, Jr. The Maxwell consumer report: Fourth-quarter and year-end 1993 sales estimates for the cigarette industry. Richmond, Virginia: Wheat, First Securities, Inc, February 10,1994 .

32 Maxwell JC, Jr. The Maxwell consumer report: fourth-quarter and year-end 1994 sales estimates for the cigarette industry. Richmond, Virginia: Wheat, First Securities, Inc, February $21,1995$.

33 McCann-Erickson Worldwide. McCann-Erickson media cost indexes. Table 2: media circulation change indexes: 1970-1997. New York: McCann-Erickson Worldwide, 1998

34 Pollay, RW, Siddarth S, Siegel M, et al. The last straw? Cigarette advertising and realized market shares among youths and adults, 1979-1993. Fournal of Marketing 1996;60:116.

35 Volk RJ, Edwards DW, Lewis RA, et al. Smoking and preference for brand of cigarette among adolescents. F Substance Abuse 1996;8:347-59.

36 Pierce JP, Choi WS, Gilpin EA, et al. Tobacco industry promotion of cigarettes and adolescent smoking. $\mathscr{f} A M A$ 1998;279:511-5.

37 Huang PP, Burton D, Howe HL, et al. Black-white differences in appeal of cigarette advertisements among adolescents. Tobacco Control 1992;1:249-55. 